\title{
春椎カリエス亀背変形と麻痺
}

$\begin{array}{llllll}\text { 総合せき損センター・整形外科 } & & & \\ \text { 小 } & \text { 原 } & \text { 伸 } & \text { 夫・芝 } & & \text { 啓一郎 } \\ \text { 植 } \text { 田 } & \text { 尊 } & \text { 善・白 } & \text { 澤 } & \text { 建 } & \text { 蔵 } \\ \text { 大 } \text { 田 } & \text { 秀 } & \text { 樹・森 } & & \text { 英 } & \text { 治 } \\ \text { 力 丸 } & \text { 俊 } & \text { 一・檜 } & \text { 田 } & \text { 伸 } & \text { 一 } \\ \text { 久 我 } & \text { 尚 } & \text { 之・達 } & \text { 城 } & & \text { 大 }\end{array}$

\section{Spinal Paraplegia in Tuberculous Spondylitis with Kyphotic Deformity}

by

Nobuo Kobara, Keiichiro Shiba, Takayoshi Ueta, Kenzo Shirasawa, Hideki Ohta, Eiji Mori,

Shunichi Rikimaru, Shinichi Hida,

Naoyuki Kuga and Dai Tatsushiro

Department of Orthopaedic Surgery,

Spinal Injury Center

We reviewed ten cases of tuberculous spondylitis with kyphotic deformity with special reference to the cause of paraplegia. Paraplegia was due to abscess in six cases, metastatic tumor is two and intradural tuberculoma in one. In the remaining case, vertebral instability just below the kyphotic spine caused paraplegia. The present study indicated that kyphotic deformity might rarely cause paraplegia solely, although such deformity over long periods tends to make spinal cords susceptible to compression.

\section{はじめに}

脊椎カリエス亀背変形患者における麻瘏発症には, 種々の要因が考えられる.しかし高度の亀背変形を有 するにもかかわらず, 麻痺症状を呈しない症例もしば しば観察される.今回我々は, 脊椎カリエス亀背変形 患者で麻瘏症状を呈した症例について，その画像所見， 手術時所見等から麻痺の原因について検討し, 後弯変 形と麻瘦発症との関係について検討したので報告す る。

\section{対象及び方法}

症例は $50^{\circ}$ (以下 Cobb 法) 以上の後弯変形をきたし た脊椎カリエス患者で, 麻盘を合併した男性 7 例, 女
性 3 例，計 10 症例，年齢は 40 歳から 75 歳，平均は 56.6 歳であった。後弯変形の角度は, $50^{\circ}$ から $132^{\circ}$, 平均は 88.7゚であった．入院時あるいは手術前の麻舫の程度 は, Frankel 評価で, A：1例, B：1例, C：7例, D：1例であった。 その画像所見, 手術時所見, 術後経 過等から麻痷発症の原因について検討した（表 1 ）。

$$
\text { 結果 }
$$

麻㽻発症の原因として, 膿瘍による圧迫 6 例（頂椎 部での圧迫 5 例, 頂椎部より離れた部位での圧迫 1 例), 悪性腫崵の頂椎部への転移 2 例, 亀背部の隣接椎 間の不安定性に伴うもの 1 例, 硬膜内結核腫によるも の1例であった（表 2 ). 
表 1 対象症例

\begin{tabular}{|c|c|c|c|c|}
\hline 症例 & 性別 & 年齢 & $\begin{array}{c}\text { 麻 } \\
\text { (Frankel 舫 } \\
\text { 洒) }\end{array}$ & $\begin{array}{l}\text { 後 } \\
\text { (部 }\end{array}$ \\
\hline 1 & M & 52 & B & $132^{\circ}$ (T 9-L 2) \\
\hline 2 & $\mathrm{~F}$ & 71 & $\mathrm{C}$ & $110^{\circ}$ ( T 12-L 1) \\
\hline 3 & M & 41 & $\mathrm{C}$ & $123^{\circ}(\mathrm{L})$ \\
\hline 4 & $\mathrm{~F}$ & 66 & $\mathrm{C}$ & $72^{\circ}$ ( T 8-L 2) \\
\hline 5 & M & 55 & $\mathrm{C}$ & $75^{\circ}$ ( T 10-L 2) \\
\hline 6 & M & 67 & A & $60^{\circ}(\mathrm{T} 7-\mathrm{T} 9)$ \\
\hline 7 & M & 40 & $\mathrm{C}$ & $113^{\circ}$ (T 4-L 4) \\
\hline 8 & $\mathrm{~F}$ & 75 & $\mathrm{D}$ & $50^{\circ}$ ( T 6-T 8) \\
\hline 9 & M & 59 & $\mathrm{C}$ & $67^{\circ}(\mathrm{T} 8-\mathrm{L} 12)$ \\
\hline 10 & M & 40 & C & $85^{\circ}$ ( T 8-L 4) \\
\hline 平均 & & 56.6 & & $88.7^{\circ}$ \\
\hline
\end{tabular}

表 2 麻痺の原因

\begin{tabular}{|c|c|c|c|}
\hline 症例 & 性別 & 年桠命 & 原 \\
\hline 1 & M & 52 & 膿 \\
\hline 2 & $\mathrm{~F}$ & 71 & 悪性腫洦転移 \\
\hline 3 & M & 41 & 結 核 腫 \\
\hline 4 & $\mathrm{~F}$ & 66 & 不安定性 \\
\hline 5 & M & 55 & 膿 \\
\hline 6 & M & 67 & 悪性腫瘍転位 \\
\hline 7 & M & 40 & 膿 \\
\hline 8 & $\mathrm{~F}$ & 75 & 11 \\
\hline 9 & M & 59 & ") \\
\hline 10 & M & 40 & "1 \\
\hline
\end{tabular}

症

例

\section{症例 1}

52 歳, 男性, Frankel B, T 9 L 2 の $132^{\circ}$ の後弯変 形, 奉髄腔造影では T 5/6での完全ブロックを認め, MRI でT 5, 6 椎体の変性とその後方にやや高信号な 腫溜を認め, 春髄は前方上り圧迫を受けていた(図 1 ). T 4 7 前方除圧固定術施行, 術中硬膜前面に乾酪壊死 物質を認め可及的に摘出した. Frankel D 改善, 膿 瘍による圧迫が原因と考えられた。

\section{症例 2}

71 歳, 女性, Frankel C, 2 年前に Grawitz 腫瘍に よる腎摘出の既往あり. T 12〜 L 1 の $110^{\circ}$ の後弯変形, 断層像にて骨融解像と腐骨を認め, 春髄腔造影では T 12/L 1 での完全ブロック, 造影後 CTにて T 12 レ ベルで腫瘤による瓷髄の圧迫と完全ブロックヨ認めた (図 2 ). T 12 L 1 前方除圧, 後方固定術施行. 術中 T12部にて暗赤色の軟らかい腫瘤組織を認め硬膜を

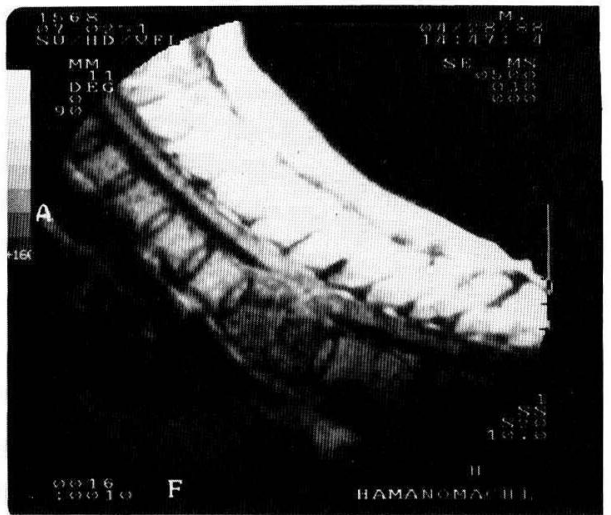

図 1 症例 1

MRI $\mathrm{T}_{1}$ 強調画像で第 5,6 胸椎の変性とその後右にや や高信号な腫瘤を認め, 春髄を圧迫している.

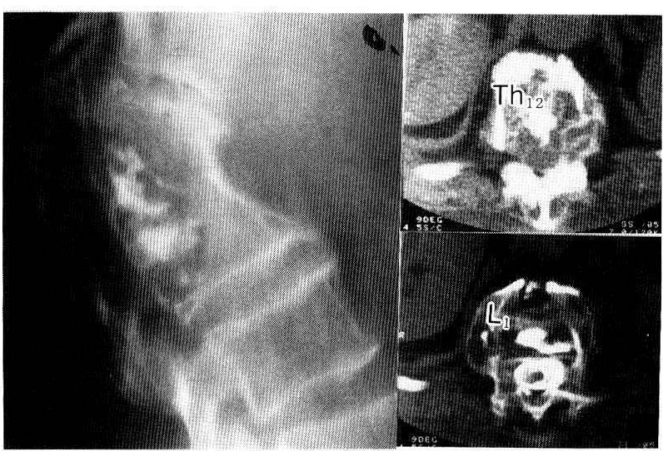

図 2 症例 2

$\mathrm{a} \mid \mathrm{b}$

a）断層像： $\mathrm{T}_{12} \sim \mathrm{L}_{1}$ の $110^{\circ}$ の後弯変形骨破壊像と腐骨陰 影を認める.

b, c) 造影後 CT： $\mathrm{Th}_{12}$ 部で腫瘤による有髄の圧迫と完全 ブロックを認める。

著明に压迫していた。病理にて Grawitz 腫瘍の転移の 診断を得た。

症例 3

41 歳, 男性, Frankel C, 腰部の $123^{\circ}$ の後弯変形, 脊髄腔造影での完全ブロック部に一致して CTにて硬 膜内に石灰化が認められた. MRI で T 1 強調, T 2 強 調画像にて低信号の腫晹が脊柱管内に認められ，GdDTPAにより著明に enhance された (図 3 ). 術中硬 膜内髄外に石灰化を伴う腫瘍を認め全摘した。病理に て結核腫と診断された. Frankel Dへ改善. 結核腫が 


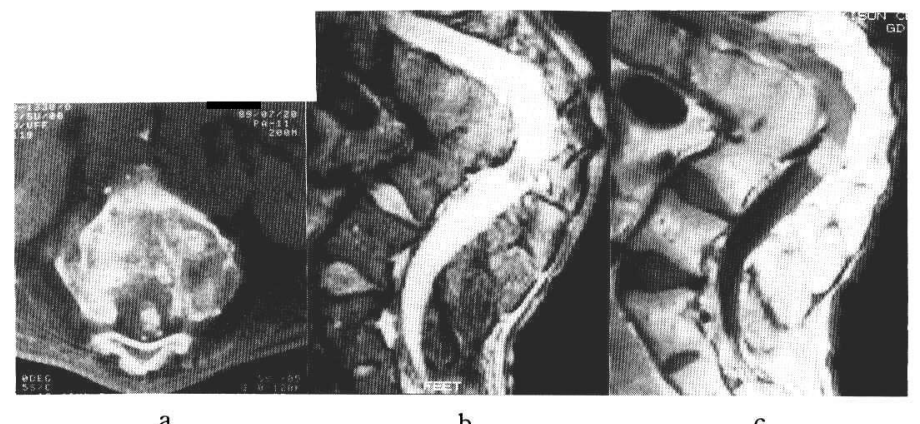

a

b

図 3 症例 3

a）奉髄腔造影での完全ブロック部に一致して，CTにて石灰化が認められる.

b) MRI $\mathrm{T}_{2}$ 強調画像 : 低信号の腫瘤が奉柱管内に認められる.

c）Gd-enhance：同腫蹈は Gd-DTPAにより著明にenhance された.

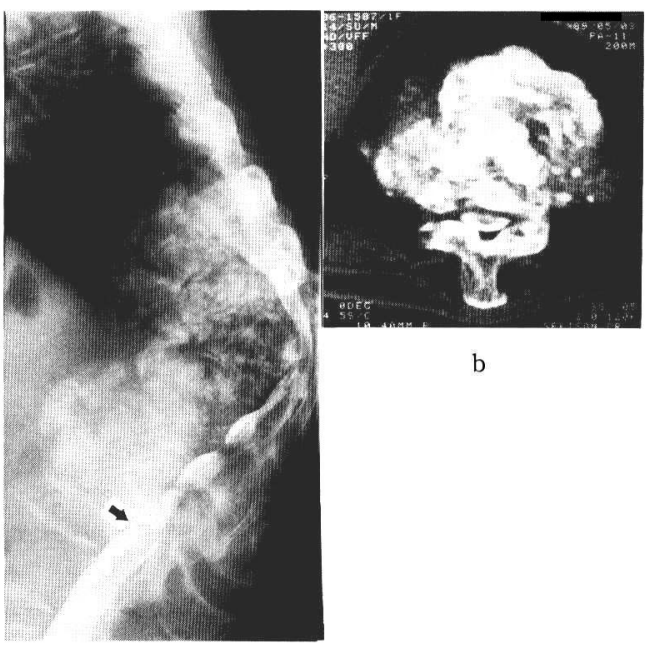

図 4 症例 4

a) 冷髄腔造影：後弯部での硬膜外からの圧排, $\mathrm{L}_{2}$ レベル （矢印）での不完全ブロック所見あり.

b) 造影後 CT (頂椎部)

帮柱管狭窄と春髅の扁平化を認める。

原因と考えられた。

症例 4

66 歳, 女性, Frankel C, T 8 L 2 の $72^{\circ}$ の後弯変形, 脊髄腔造影にて後弯部での硬膜外からの圧排, L 2 レ ベルでのブロック所見あり。造影後 CT で頂椎部での 脊柱管狭窄, 奉髄の扁平化認められた(図 4). T 6〜L 4 の Cotrel Dubousset instrument 孝用いた後方固定術 施行. 術中 L $1 / 2$ 間の著明な不安定性を認め, 骨移植に
よる後方固定を加えた. Frankel D へ改善. 不安定性 が原因と考えられた。

症例 5

55 歳, 男性, Frankel D, T 10〜 L 2 の $75^{\circ}$ の後弯変 形. MRIにて T 11〜T 12 レベルで有髄の後方に Gd DTPA で enhance される膿晹を認め, T 12 の椎体, 左 椎弓根にも膿瘍が認められ, axial 像にて春髄は後方 より著明に圧迫されていた（図 5 ). 肋骨横突起切除, 搔爬術施行. Frankel D 改善. 膿瘍による圧迫が原 因と考えられた。

\section{考察}

従来より, 亀背変形による脊髄の伸展, 頂椎部での 骨性の圧迫のための血行障害も麻痺発症の原因と考え られてきた. しかし, 高度の亀背変形を有しながら麻 痺症状を呈さない症例もしばしば経験される。脊椎力 リエス亀背変形患者に合併する遅発性春髄麻痺の発症 の原因としては, 病巣再燃に伴う膿瘍, 肉芽組織によ る圧迫のほか, 腐骨による圧迫, 亀背変形による脊柱 管狭窄, 椎間の不安定性, 骨破壊による病的骨折, 脊 椎の脱臼が報告されている11. また，結核性髄膜炎，ま れではあるが金髄内の結核や，硬膜の洀痕化による麻 痺発生の報告もある。

今回検討を加えた 10 症例中, 悪性腫瘍の転移が原因 と考之られた 2 症例を除く 8 症例全例で，手術による 固定ないし除圧により麻痺に改善が認められており， 特に症例 4 では, 後弯の矯正を得られなかったにもか かわらず，除圧を行わず不安定椎間固定のみで麻㽻に 改善を認めた。このことより，長年にわたる後弯変形 


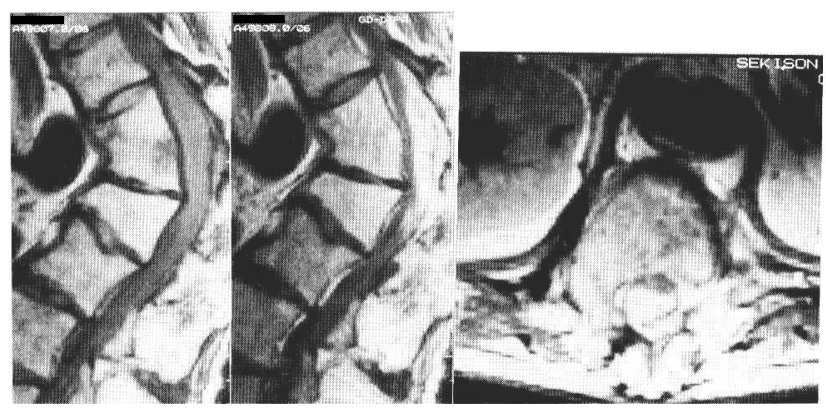

a

b

c

図 5 症例 5

a) MRI Gd-enhonce (-)

b) MRI Gd-enhance (+)

$\mathrm{Th}_{11-12}$ レベル後方に Gd-DTPAにより著明に enhanceされる膿 瘍を認める。

c) axial 像 $(\mathrm{Gd}$-enhance $(+))$

脊䯣は enhance された膿瘍により後方より圧迫されている. 左椎弓 根にも膿崵を認める。

のために，容易に麻㽻を発症しやすい状態にあること は考えられるが3), 後弯変形のみが麻痺の主因となる ことは稀であり, 麻痺発症には他の何らかの病態が加 わっていると推察される4).

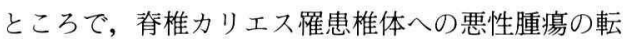
移は少ないといわれているが, 今回 2 症例で最近は脊 椎カリエス発生に高齢化の傾向があると言われてお $\eta^{2)}$, この 2 症例も 71 歳と 67 歳と高齢であった. 高齢 者の麻痺合併例では, 悪性腫瘍の転移にも十分配慮し て, 検索を進めていく必要があると思われた。

\section{ま と め}

1. 脊椎カリエス亀背変形患者で麻痺を合併した 10 症例について, 麻痺の原因を検討した。

2. 膿瘍による圧迫 6 例（頂椎部での圧迫 5 例, 頂 椎部より離れた部位での圧迫 1 例), 悪性腫瘍の頂椎部 への転移 2 例, 亀背部の隣接椎間の不安定性 1 例, 硬
膜内結核腫 1 例であった。

3. 後弯変形のみが麻痺の主因となることは稀と考 えられた。

4. 高歯者の麻痺合併例では悪性腫瘍の転移の鑑別 を要する.

\section{参 考 文 献}

1) Hodgson, A. R., Yau, A., Kwon, J. S., et al.,: A Clinical Study of 100 Consecutive Cases Pott's Paraplegia: Clin. Orthop. 36 : 128-150, 1964.

2）樫本 修・他：最近 5 年間の春椎カリエス手術例の 検討. 骨, 関節感染症, $3: 92-94,1989$.

3）大谷 清, 米山芳夫, 相原忠彦, 他 : 春柱後弯症に対 する手術的治療法とその成績, 臨整外, $19: 875-884$, 1984.

4）力丸俊一・他：春椎力リエスに対する手術治療例の 検討. 整外と災害, 39：313-317, 1990. 